\title{
THE USES OF MORINGA CAPSULES WITH NANOGOLD AS DRUG DELIVERY AND NANO-SILVER AS ANTIVIRAL FOR IMMUNE IMPROVEMENT OF COVID19 PATIENTS
}

\author{
Najlatun Naqiyah ${ }^{1}$, Titik Taufikurohmah ${ }^{2} \square$ (D), Ananto Sidohutomo \\ ${ }^{1}$ Counseling Guidance Department, Universitas Negeri Surabaya, Indonesia \\ ${ }^{2}$ Department of Chemistry, Universitas Negeri Surabaya, Indonesia \\ ${ }_{3}^{3}$ Medisian, Cancer Museum Indonesia, Surabaya, Indonesia.
}

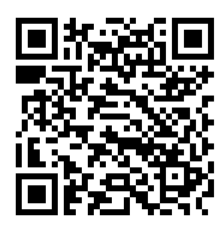

Received 14 October 2021

Accepted 14 November 2021

Published 30 November 2021

\section{CorrespondingAuthor}

Titik Taufikurohmah,

titiktaufikurohmah@unesa.ac.id

DOI

10.29121/granthaalayah.v9.i11.2021 .4347

Funding: This research received no specific grant from any funding agency in the public, commercial, or not-for-profit sectors.

Copyright: (C) 2021 The Author(s). This is an open access article distributed under the terms of the Creative Commons Attribution License, which permits unrestricted use, distribution, and reproduction in any medium, provided the original author and source are credited.

\section{ABSTRACT}

Improving the immunity of COVID-19 patients is very important for the healing process. As is known, viral diseases, including COVID-19, cannot be treated. What can be done is to increase the body's immune system to be strong against the virus attack and weaken it. Various efforts to increase immunity are carried out, among others, with Moringa capsules containing nanogold and nano-silver. Nanogold as drug delivery and nano-silver as antiviral. A total of 64 COVID-19 patients who were treated using Moringa capsules routinely showed a significant recovery process. Clinical trial volunteers were grouped into 3 categories. The first group of positive COVID-19 asymptomatic 22 people. The second group of 24 COVID-19 positive people with mild to moderate symptoms, including experiencing fever, cough, runny nose, and weakness. The 3rd group of 18 people were COVID-19 patients with severe conditions with respiratory problems to the point of using a ventilator. The results of the clinical trial showed that the first group of Covid-19 patients recovered after consuming Moringa capsules for 1-2 weeks, the second group recovered 3-6 weeks. The 3rd group recovered 4-8 weeks. In conclusion, it is proven that Moringa capsules with nanogold and nano-silver increase the immunity of Covid-19 patients so that they survive and recover from their pain. The length of time required for recovery is different for each group. The first group recovered faster than the second group. The third group recovered the longest. It is highly recommended to use Moringa capsules with nanogold and nano-silver innovations to recover COVID-19, especially the new variants that are more easily spread.

Keywords: Moringa Capsule, Body Immune, Nanogold, Nano-Silver, Covid19

\section{INTRODUCTION}

Boosting the body's immune system is very necessary for COVID-19 patients. As we all know, COVID-19 is a disease caused by a virus for which there is no cure. One way to recover from COVID-19 is to increase the body's immune system Syamaidzar (2020). The body's immune system will attack and weaken the virus so that it does not grow in number and cannot penetrate cells. Furthermore, this weakened virus enters the secretory system and leaves the body. It is by reducing the amount of virus from the body that the process of recovery and healing occurs Novitasari (2021). Increasing the body's immune system can be done by consuming various plants that contain antioxidant compounds, including Moringa plants. Moringa plants contain various types of antioxidants, including poly phenols, flavonoids, tannins, chlorophyll, vitamins and other secondary metabolites Moustafa and Mansour (2020).These antioxidant compounds will reduce free radicals and increase the body's immune 
system. A great immune system is able to ward off various diseases that come from both bacteria and viruses Sodagari et al. (2016).

Nanogold in Moringa capsules functions as a carrier of antioxidant active compounds to receptors known as drug delivery S. V. et al (2014). The various active compounds of the Moringa plant are large, spaced molecules. This makes it difficult to move and is distributed to the parts of the body that need it. Nanogold accelerates the movement of the active compound because in addition to being small, nanogold is also not charged Alanazi et al. (2010). Non-polar compounds are difficult to enter the bloodstream, which tends to be polar, so nanogold makes it easier for these compounds to enter the bloodstream. Polar compounds are also difficult to penetrate cell walls consisting of lipo-proteins, nanogold also makes it easier for them to enter and penetrate cell walls. This is the basis of the ability of nanogold as a carrier agent for active drug compounds to meet receptors that need it Batory et al. (2016). Thus, the efficacy of the drug is increased and the healing process is faster Murai et al. (2013).

Apart from being a drug delivery agent, Nanogold also has antioxidant activity which is able to reduce free radicals that enter the body Taufikurohmah et al. (2012). The antioxidant activity of nanogold is even greater than that of vitamins, which is 10 times that of vitamins. Thus, nanogold has the potential to increase immunity for COVID-19 patients during the pandemic Taufikurohmah et al. (2020). Nanogold also increases glutathione activity in the body. Glutathione is an endogenous antioxidant present in cells that protects cells from inflammation and oxidative damage Dkhil et al. (2015). Thus, using nanogold in Moringa capsules for consumption by COVID-19 patients is very appropriate Katsnelson et al. (2013).

Nano-silver in Moringa capsules functions as an antiviral that interferes with the process of replicating viruses so that the number of viruses does not increase, thus being easily weakened and expelled from the body through the excretory system Taufikurohmah and Soepardjo, (2019). Nano-silver is small enough to enter the RNA of the Corona virus, including the virus that causes covid19 Novitasari (2021). The nano-silver interacts with the amino acids in the RNA and causes the bonds to not be formed so that there is no new RNA replica of the new virus. This is the mechanism for destroying the replica of the corona virus carried out by nanosilver Mehrbod et al. (2009). Thus, nano-silver in Moringa capsules for COVID-19 patients is appropriate Taufikurohmah et al. (2021).

This clinical trial is intended to immediately obtain clinical data for the gradual recovery of COVID-19 patients by consuming Moringa capsules containing nanogold and nano-silver. This data is very important to be recommended to the public. The public is expected not to doubt the power of Moringa capsule herbal medicine with nanogold and nano-silver. Then immediately applied widely and taken care of licensing, namely the distribution permit from BPOM. It's very easy to find volunteers for clinical trials during the covid19 pandemic season. They are very enthusiastic because they want to get well soon from covid19.

\section{METHOD}

A total of 64 COVID-19 patients were divided into three groups according to the level of symptoms. The first group of positive COVID-19 patients was asymptomatic 22 people. The second group of 24 COVID-19 positive people with mild to moderate symptoms, including experiencing fever, cough, runny nose, and weakness. The 3rd group of 18 people were COVID-19 patients with severe symptoms with respiratory problems to the point of using a ventilator. 


\subsection{MATERIAL}

Moringa capsule material used in clinical trials contains nanogold and nanosilver. Moringa material as the basic ingredient of Moringa capsules is made by drying the leaves of the Moringa plant. Drying using a fresh-dry machine that is drying at low temperatures with low pressure for 8 hours. This process ensures that the active compounds in Moringa leaves are not damaged. After drying, the Moringa leaves are ground with a grinding machine. The resulting Moringa leaf powder is then added with nanogold and nano-silver colloids. Nanogold and nano-silver are absorbed in Moringa leaf powder. Moringa leaf powder becomes slightly moist and dried again using a fresh-dry machine for 1 hour. The next process is to put $500 \mathrm{mg}$ Moringa-nanogold-nano-silver (NG-NS) powder in the capsule shell. Moringa NG-NS capsules were put in bottles of 60 seeds per bottle and were ready to be used for clinical trials.

\subsection{CLINICAL TEST TREATMENT}

64 COVID-19 patient volunteers consisting of 22 asymptomatic people, 24 people with mild to moderate symptoms and 18 people with severe symptoms. The treatment for the three groups of volunteers was the same, namely given one bottle of $500 \mathrm{mg}$ Moringa capsules to be consumed as much as 2 capsules three times a day. Supervision of the treatment was carried out every day by the researcher. Health checks and COVID-19 status are carried out once a week. Volunteer Covid19 status is done by PCR test. Data is recorded and recorded in the research logbook. The data is then analysed as study material.

\section{RESULT AND DISCUSSION}

A total of 64 COVID-19 patients consisting of 22 people were included in the first group of positive COVID-19 asymptomatic. The second group of 24 COVID-19 positive people with mild symptoms, including experiencing fever, cough, runny nose, and weakness. The 3rd group of 18 people were COVID-19 patients with severe conditions with respiratory problems to the point of using a ventilator. The results of the clinical trial showed that the first group of Covid-19 patients recovered after consuming Moringa capsules for 1-2 weeks, the second group recovered 3-6 weeks. The 3rd group recovered 4-8 weeks. More complete data is presented in Table 1, Table 2, Table 3 which is clarified by the bar chart in Figure 1, Figure 2, Figure 3 below:

Table 1 The Result of Clinical Test Covid19 Asymptomatic Group.

\begin{tabular}{|c|c|c|c|c|c|c|c|}
\hline \multirow[t]{2}{*}{ Volunteer } & \multirow{2}{*}{$\begin{array}{l}\text { Body Temperature } \\
\left({ }^{\circ} \mathrm{C}\right)\end{array}$} & \multirow{2}{*}{$\begin{array}{l}\text { Blood Pressure } \\
\text { (mmHg) }\end{array}$} & \multirow{2}{*}{$\begin{array}{c}\text { Heart Rate } \\
\text { (number/minute) }\end{array}$} & \multicolumn{4}{|c|}{ Covid19 Status } \\
\hline & & & & Week1 & Week2 & Week3 & Week4 \\
\hline Vol-2 & 36,7 & 117 & 90 & + & + & - & - \\
\hline Vol-3 & 36,7 & 123 & 80 & + & - & - & - \\
\hline Vol-6 & 36,6 & 120 & 90 & + & + & - & - \\
\hline Vol-7 & 36,7 & 117 & 80 & + & + & - & - \\
\hline Vol-8 & 36,7 & 116 & 70 & + & - & - & - \\
\hline Vol-9 & 36,6 & 120 & 70 & + & - & - & - \\
\hline
\end{tabular}




\begin{tabular}{|c|c|c|c|c|c|c|c|}
\hline Vol-10 & 36,5 & 113 & 80 & + & + & - & - \\
\hline Vol-11 & 36,6 & 110 & 70 & + & - & - & - \\
\hline Vol-12 & 36,6 & 110 & 70 & + & - & - & - \\
\hline Vol-13 & 36,5 & 113 & 80 & + & + & - & - \\
\hline Vol-14 & 36,6 & 116 & 80 & + & + & - & - \\
\hline Vol-15 & 36,7 & 117 & 70 & + & - & - & - \\
\hline Vol-16 & 36,7 & 120 & 70 & + & - & - & - \\
\hline Vol-17 & 36,6 & 120 & 90 & + & + & - & - \\
\hline Vol-18 & 36,5 & 121 & 80 & + & - & - & - \\
\hline Vol-19 & 36,6 & 123 & 70 & + & - & - & - \\
\hline Vol-20 & 36,6 & 117 & 80 & + & - & - & - \\
\hline Vol-21 & 36,5 & 116 & 90 & + & + & - & - \\
\hline Vol-22 & 36,7 & 121 & 90 & + & + & - & - \\
\hline \multicolumn{4}{|c|}{ The number of Volunteer that recovery Covid19 } & 0 & 12 & 22 & 22 \\
\hline
\end{tabular}

- Notes that the PCR-test of Volunteer declared negative Covid19

Table 1 provides information on COVID-19 volunteers from the asymptomatic group (22 people) who have recovered after routinely consuming Moringa-NG-NS capsules for one week. The number of Covid-19 volunteers who were declared cured was 12 people. The following week all the asymptomatic group of Covid-19 volunteers recovered completely. They recover easily because their immune system is still good. This is indicated that they do not show symptoms of illness even though they are tested positive for COVID-19. Moringa-NG-NS capsules really help improve the body's immune system so that asymptomatic conditions persist until they are declared cured or negative for COVID-19 from the PCR test. This is strongly supported by the theory that nanogold enhances immunity by activating glutathione Zheng et al. (2013). Glutathione is an endogenous antioxidant that belongs to the cellular level.

Nano-silver also helps by attacking viruses in the body so that they are unable to replicate Zivic et al. (2017), Taufikurohmah and Soepardjo (2019). Likewise, Moringa leaf extract has secondary metabolites that help the body ward off free radicals Moustafa and Mansour (2020). The body survives from viral attacks, free radicals and the glutathione system increases. So even though they were tested positive for COVID-19, the volunteers did not show symptoms and one week later they were declared negative. The average body temperature of volunteers in this group was also in the normal range of healthy people Hajimonfarednejad et al. (2018). Likewise, the blood pressure and heart rate of all volunteers during clinical trials were in the normal range of healthy people. Figure 1. Explains the recovery process of volunteers in this group where a week after consuming more than half of the volunteers have recovered. There was no increase in complaints and symptoms indicating the strength of the volunteers' immune Taufikurohmah et al. (2021). 


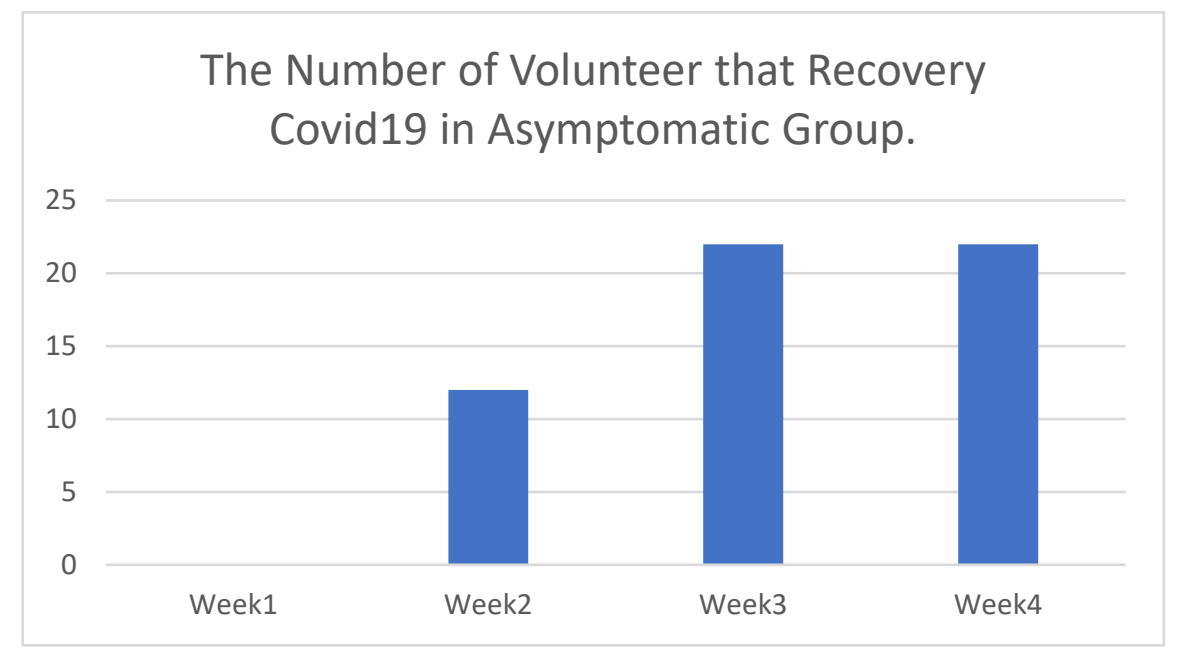

Figure 1 The Recovery Process of Covid19 at Asymptomatic Group

Nanogold helps the body increase the activity of glutathione, an endogenous antioxidant that already exists at the cellular level Katsnelson et al. (2013). Nanosilver helps the body paralyze the Covid19 virus by disrupting the replica of the virus so that it does not grow in number and does not increase symptoms in the volunteer's body Francis et al. (2018). Moringa leaf extract which contains antioxidant compounds also helps the immune system to fight incoming viruses Hashem et al. (2016). The synergy of these three materials causes the body to be ready to face the Covid-19 attack so that it recovers and survives the negative Covid19 status at the next examination. This is experienced by the group of Covid19 volunteers with mild to moderate symptoms.

\begin{tabular}{|c|c|c|c|c|c|c|c|c|}
\hline \multirow[t]{2}{*}{ Volunteer } & \multirow{2}{*}{$\begin{array}{c}\text { Body } \\
\text { Temperature } \\
\left({ }^{\circ} \mathrm{C}\right)\end{array}$} & \multirow{2}{*}{$\begin{array}{c}\text { Blood Pressure } \\
\text { (mmHg) }\end{array}$} & \multirow{2}{*}{$\begin{array}{c}\text { Heart Rate } \\
\text { (number/ } \\
\text { minute) }\end{array}$} & \multicolumn{5}{|c|}{ Covid19 Status } \\
\hline & & & & Week1\&2 & Week3 & Week4 & Week5 & Week6 \\
\hline Vol-1 & 36,6 & 122 & 80 & + & + & + & - & - \\
\hline Vol-2 & 36,6 & 119 & 80 & + & + & + & - & - \\
\hline Vol-3 & 36,5 & 120 & 90 & + & + & - & - & - \\
\hline Vol-4 & 36,7 & 119 & 70 & + & - & - & - & - \\
\hline Vol-5 & 36,6 & 116 & 70 & + & + & - & - & - \\
\hline Vol-6 & 36,5 & 122 & 80 & + & + & + & + & - \\
\hline Vol-7 & 36,6 & 118 & 90 & + & + & + & - & - \\
\hline Vol-8 & 36,7 & 117 & 80 & + & + & + & + & - \\
\hline Vol-9 & 36,5 & 121 & 90 & + & + & + & - & - \\
\hline Vol-10 & 36,6 & 114 & 80 & + & + & + & + & - \\
\hline Vol-11 & 36,7 & 112 & 90 & + & + & + & - & - \\
\hline Vol-12 & 36,8 & 113 & 90 & + & + & - & - & - \\
\hline Vol-13 & 36,6 & 110 & 90 & + & + & + & + & - \\
\hline Vol-14 & 36,7 & 114 & 70 & + & - & - & - & - \\
\hline Vol-15 & 36,6 & 116 & 80 & + & + & + & - & - \\
\hline Vol-16 & 38,6 & 121 & 90 & + & + & + & - & - \\
\hline Vol-17 & 37,5 & 122 & 80 & + & + & + & + & - \\
\hline Vol-18 & 37,6 & 120 & 90 & + & + & - & - & - \\
\hline
\end{tabular}




\begin{tabular}{cccccccc}
\hline Vol-19 & 37,7 & 120 & 90 & + & + & + & + \\
Vol-20 & 38,5 & 118 & 80 & + & + & + & - \\
Vol-21 & 37,5 & 119 & 70 & + & - & - & - \\
Vol-22 & 36,7 & 120 & 80 & + & + & + & - \\
Vol-23 & 36,5 & 120 & 90 & + & + & - \\
Vol-24 & 36,5 & 120 & 90 & + & - & - \\
The number of Volunteer that recovery Covid19 & & & - \\
+
\end{tabular}

It can be seen from the data in Table 2 that no COVID-19 volunteers in the group with mild to moderate symptoms have recovered until the 2 nd week. The 3 rd week only 3 people recovered. After that in the 4 th week as many as 10 people were declared cured. Week 5 more than half the number of volunteers, namely 17 people recovered from Covid19. Week 6 uke all volunteers from this group recovered. It took longer for all volunteers to heal than the asymptomatic group. This is because the treatment received is the same as the asymptomatic group. They should have received a larger dose so that the recovery time was the same as the asymptomatic group. Increasing the dose is not dangerous because Moringa leaves or herbs do not harm the body. Even the accumulation of active herbal compounds will accelerate disease recovery Hashem et al. (2016). The body temperature of some volunteers is above the average body temperature of healthy people, but most of the normal body temperatures of healthy people. Blood pressure and heart rate in general did not differ from the asymptomatic group, which is in the normal range of healthy people. The herbal capsules Moringa-NG-NS did not harm blood pressure or heart rate in volunteers. There was no difference in the value of blood pressure or heart rate during treatment Khorshidian et al. (2018).

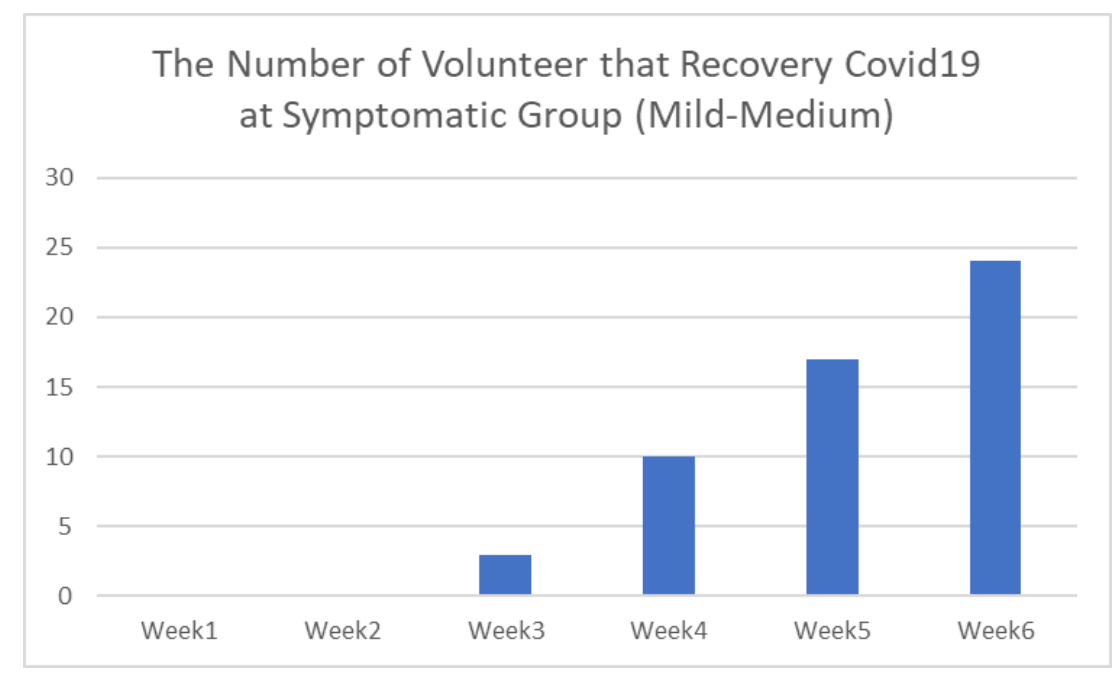

Figure 2 The Recovery Process of Covid19 at Symptomatic Group (Mild-Medium)

Table 3 The Result of Clinical Test Covid19 Symptomatic Group (Severe)

\begin{tabular}{|c|c|c|c|c|c|c|c|c|c|}
\hline \multirow[t]{2}{*}{ Volunteer } & \multirow{2}{*}{$\begin{array}{l}\text { Body Tempe. } \\
\left({ }^{\circ} \mathrm{C}\right)\end{array}$} & \multirow{2}{*}{$\begin{array}{c}\text { Blood } \\
\text { Press. } \\
\text { (mmHg) }\end{array}$} & \multirow{2}{*}{$\begin{array}{c}\text { Heart Rate } \\
\text { (number/min.) }\end{array}$} & \multicolumn{6}{|c|}{ Covid19 Status } \\
\hline & & & & $\begin{array}{c}\text { Week1, } \\
\text { 2, \&3 }\end{array}$ & $\begin{array}{c}\text { Week } \\
4\end{array}$ & $\begin{array}{c}\text { Week } \\
5\end{array}$ & $\begin{array}{c}\text { Week } \\
6\end{array}$ & $\begin{array}{c}\text { Week } \\
7\end{array}$ & $\begin{array}{c}\text { Week } \\
8\end{array}$ \\
\hline
\end{tabular}


Najlatun Naqiyah, Titik Taufikurohmah, and Ananto Sidohutomo

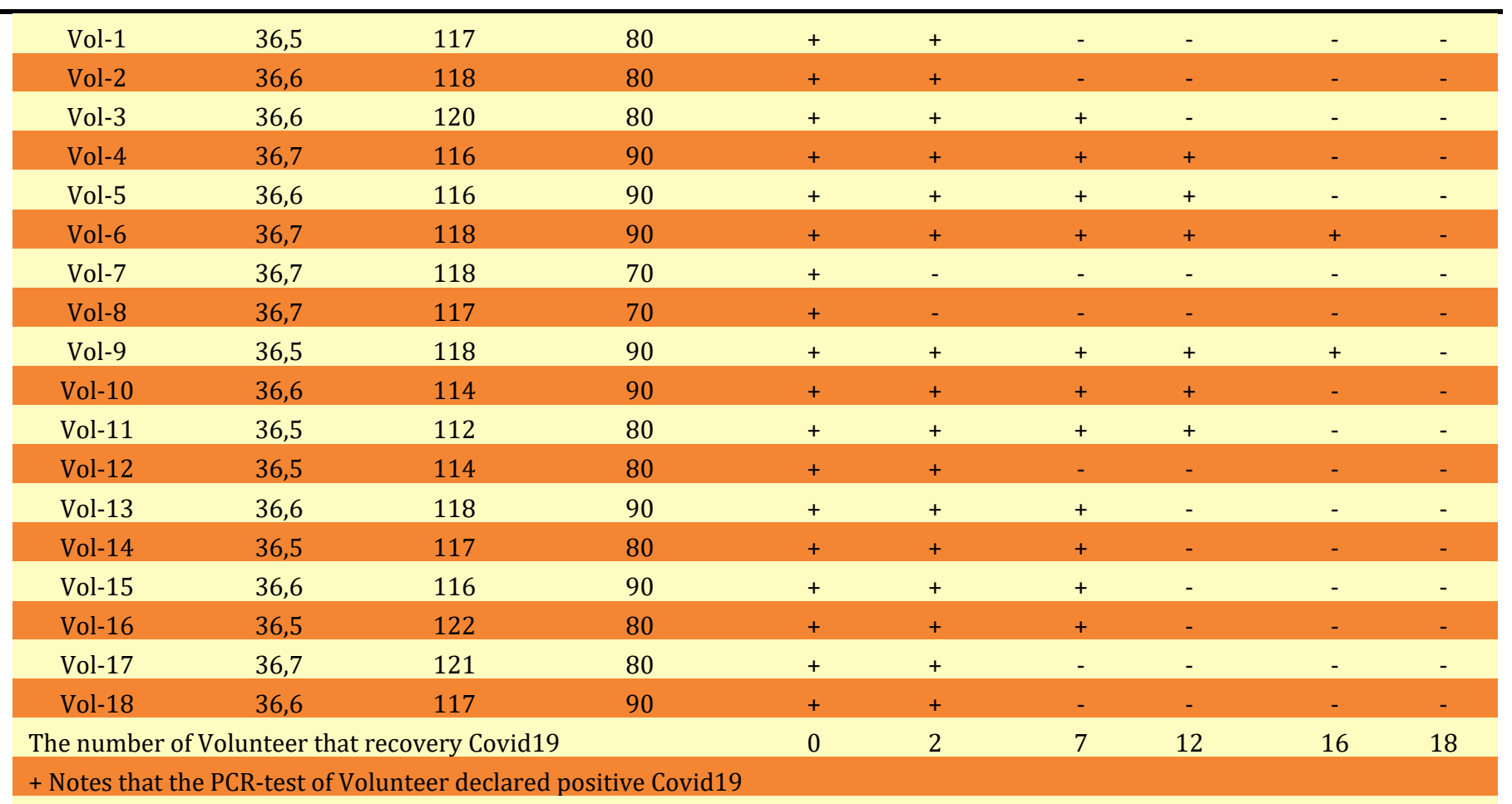

- Notes that the PCR-test of Volunteer declared negative Covid19

Volunteers in the Covid19 group clinical trial with severe symptoms took the longest time compared to other groups. However, the results are very encouraging because their fight against Covid19 was successful and did not die Ignatov (2020), Novitasari (2021). They experienced a significant reduction in shortness of breath, thereby relieving early symptoms. The treatment of this group was also the same as the two previous groups. This clinical trial provides an overview of the next dose that should be designed for volunteers with more severe symptoms Dkhil et al. (2015), Hajimonfarednejad et al. (2018). The dose should be made larger for volunteers with severe symptoms such as this group 3 . The dose can be increased or by repeating the consumption of Moringa capsules more often, for example every 4 hours again.

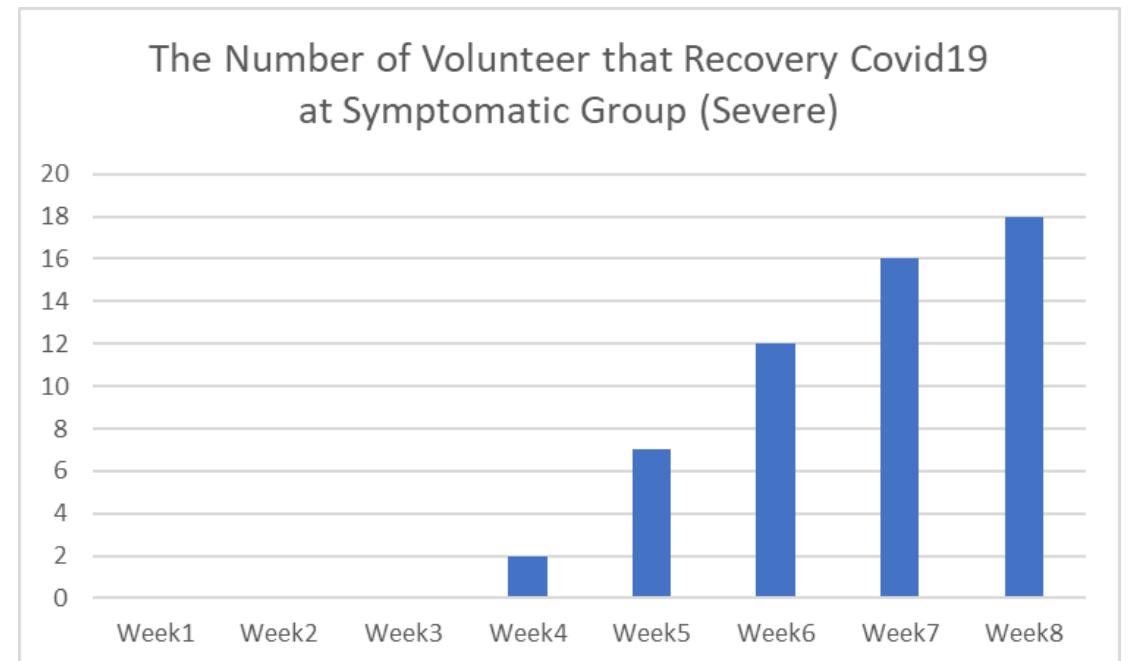

Figure 3 The Recovery Process of Covid19 at Symptomatic Group (Severe) 


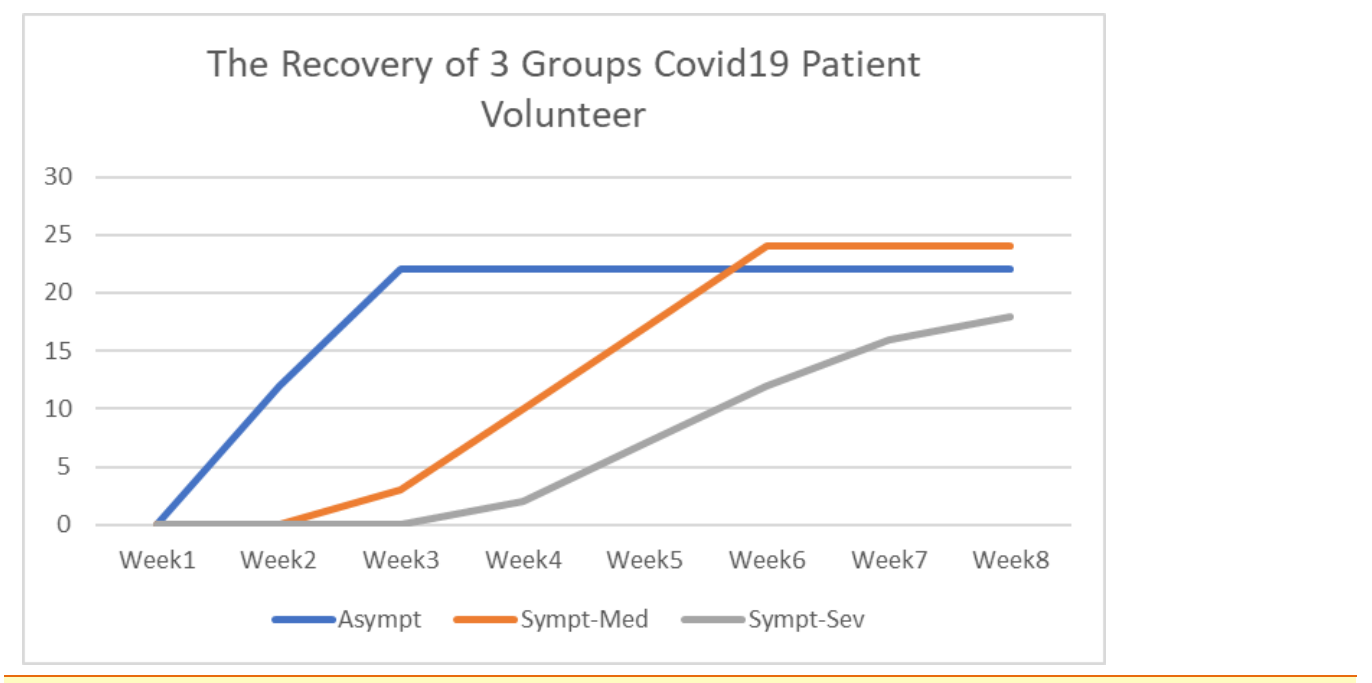

Figure 4 The Comparison of Recovery Process of 3 Groups Covid19 Patient Volunteer

Figure 4. Reinforces the recovery process of the entire Test group. By the end of the first week, the asymptomatic group of COVID-19 had recovered. In the 3rd week, the first group of asymptomatic covid19 volunteers had all recovered with a negative covid19 status until the 8th week. The chart looks flat and straight from the 3rd week. The second group of COVID-19 volunteers with mild to moderate symptoms had recovered from the 3rd week and showed full recovery at the 6th week. The chart looks flat and straight from the 6th week. The group with the most severe COVID-19 symptoms were also able to recover from illness at week 4 and fully recover at week 8 Francis et al. (2018), Kinoshita et al. (2014).

\section{CONCLUSION}

The conclusion of the clinical trial of Moringa NG-NS capsules on covid19 volunteers succeeded in increasing immunity in 3 groups of volunteers. The first group of 22 COVID-19 volunteers without symptoms, NGNS Moringa capsules proved successful in restoring volunteers from the end of the first week and fully recovered in the 3rd week. This is supported by the negative PCR swap test results for all volunteers in group 1,3-8. The second group of 24 COVID-19 volunteers with mild to moderate symptoms, Moringa NG-NS capsules were proven to be successful in recovering volunteers from the 3rd week and fully recovered by the 6th week. 18 COVID-19 volunteers with severe symptoms also recovered from the 4th week and fully recovered at the 8th week. Moringa NG-NS capsules can be relied on as an alternative to future herbal medicines for COVID-19 through the mechanism of increasing the body's immune system.

\section{ACKNOWLEDGEMENT}

Thank you to the Ministry of Education and Culture of Indonesia through the Director General of Higher Education for funding the Applied Research Scheme for Higher Education Excellence with the main contract number: 217/SP2H/LT/DRPM/2021 and the derivative contract number: B/12118/UN38.9/ LK.04.00/2021. Thanks, are also conveyed to the Universitas Negeri Surabaya through the Institute for Research and Community Service LPPM which has assisted in the disbursement of research funds. 


\section{REFERENCES}

A. A. Moustafa and S. R. Mansour, (2020) "Moringa peregrina a Natural Medicine for Increasing Immunity Defense against the COVID-19 Medicinal \& Aromatic Plants," no. July, pp. 1-8.

B. A. Katsnelson et al., (2013) "Comparative in vivo assessment of some adverse bioeffects of equidimensional gold and silver nanoparticles and the attenuation of nanosilver's effects with a complex of innocuous bioprotectors," Int. J. Mol. Sci., vol. 14, no. 2, pp. 2449-2483. Retrieved from https://doi.org/10.3390/ijms14022449

F. K. Alanazi, A. A. Radwan, and I. A. Alsarra, (2010) "Biopharmaceutical applications of nanogold," Saudi Pharmaceutical Journal, vol. 18, no. 4. pp. 179-193. Retrieved from https://doi.org/10.1016/j.jsps.2010.07.002

F. Zivic, N. Grujovic, S. Mitrovic, I. U. Ahad, and D. Brabazon, (2017) "Characteristics and applications of silver nanoparticles," in Commercialization of Nanotechnologies-A Case Study Approach. Retrieved from https://doi.org/10.1007/978-3-319-56979-6_10

H. R. Sodagari, R. Bahramsoltani, M. H. Farzaei, A. H. Abdolghaffari, N. Rezaei, and A. W. Taylor-Robinson, (2016) "Tea polyphenols as natural products for potential future management of HIV infection - an overview," J. Nat. Remedies, vol. 16, no. 2. Retrieved from https://doi.org/10.18311/jnr/2016/4782

I. Ignatov, (2020) "Anti Inflammatory and Anti Viral Effects of Potassium ( K ) and Chemical Composition of Moringa," vol. 9, no. 2, pp. 1-7. Retrieved from https://doi.org/10.9734/ajob/2020/v9i230081

M. A. Dkhil, A. A. Bauomy, M. S. M. Diab, and S. Al-Quraishy, (2015) "Antioxidant and hepatoprotective role of gold nanoparticles against murine hepatic schistosomiasis," Int. J. Nanomedicine. Retrieved from https://www.ncbi.nlm.nih.gov/pmc/articles/PMC4687720/

M. Batory et al., (2016) "The use of liposomes in the modification of polycaprolactone fibers," J. Appl. Polym. Sci. Retrieved from https://doi.org/10.1002/app.43299

M. Hajimonfarednejad, M. Ostovar, M. J. Raee, M. H. Hashempur, J. G. Mayer, and M. Heydari, (2018) "Cinnamon: A systematic review of adverse events," Clinical Nutrition. Retrieved from https://doi.org/10.1016/j.clnu.2018.03.013

M. Hashem, A. E. M. Abdalla, E. R. Abdol Raouf, A. El-Shafei, S. Zaghloul, and M. K. ElBisi, (2016) "Moringa oleifera-silver nanohybrid as green antimicrobial finishing for cotton fabrics," Egypt. J. Chem., vol. 59, no. 4. Retrieved from https://doi.org/10.21608/ejchem.2016.1200

N. Khorshidian, M. Yousefi, M. Shadnoush, and A. M. Mortazavian, (2018) "An overview of $\beta$-glucan functionality in dairy products," Curr. Nutr. Food Sci. Retrieved from https://doi.org/10.2174/1573401313666170609092748

P. Mehrbod et al., (2009) "In Vitro Antiviral Effect of " Nanosilver " on Influenza Virus," vol. 17, no. 2, pp. 88-93. Retrieved from https://www.sid.ir/en/journal/ViewPaper.aspx?ID=144384

Q. Zheng, H. Yang, J. Wei, J. long Tong, and Y. qian Shu, (2013) "The role and mechanisms of nanoparticles to enhance radiosensitivity in hepatocellular cell," Biomed. Pharmacother. Retrieved from https://doi.org/10.1016/j.biopha.2013.04.003 
S. Francis, E. P. Koshy, and B. Mathew, (2018) "Microwave Aided Synthesis of Silver and Gold Nanoparticles and their Antioxidant, Antimicrobial and Catalytic Potentials," J Nanostruct. Netrieved from https://jns.kashanu.ac.ir/article_58580.html

S. Syamaidzar, (2020) "Review Vaksin Covid-19," no. July, pp. 0-14.

S. V. et al., (2014) "Single-step green synthesis and characterization of goldconjugated polyphenol nanoparticles with antioxidant and biological activities," International Journal of Nanomedicine. Retrieved from https://www.ncbi.nlm.nih.gov/pmc/articles/PMC4211914/

T. A. Novitasari, (2021) "The Effect of Nanogold-Nanosilver for Immune Enhancement of Drug Abuse Victims in Areas Affected by COVID-19," Int. J. Curr. Sci. Res. Rev., vol. 04, no. 01, pp. 32-39. Retrieved from https://doi.org/10.47191/ijcsrr/V4-i1-06

T. Kinoshita et al., (2014) "Immuno-Electron Microscopy of Primary Cell Cultures from Genetically Modified Animals in Liquid by Atmospheric Scanning Electron Microscopy," Microsc. Microanal., vol. 20, no. 02, pp. 469-483, Apr. Retrieved from https://doi.org/10.1017/S1431927614000178

T. Murai, M. Sato, H. Nishiyama, M. Suga, and C. Sato, (2013) "Ultrastructural analysis of nanogold-labeled cell surface microvilli in liquid by atmospheric scanning electron microscopy and their relevance in cell adhesion," Int. J. Mol. Sci., vol. 14, no. 10, pp. 20809-20819. Retrieved from https://doi.org/10.3390/ijms141020809

T. Taufikurohmah and D. Soepardjo, (2019) "Herpes Disease : Case Study Of Herpes Transmission In Islamic Cottage Schools," vol. 1, no. Snk, pp. 88-94. Retrieved from https://doi.org/10.2991/snk-19.2019.22

T. Taufikurohmah, D. Soepardjo, and H. Armadianto, (2020) "Synthesis and Characterization of Nanogold-Nanosilver Cluster Diameter Using UV-Visible Instruments and TEM Electron Microscope Transform Instruments," vol. 390, no. Icracos 2019, pp. 146-151. Retrieved from https://doi.org/10.2991/icracos-19.2020.31

T. Taufikurohmah, G. M. Sanjaya, A. Baktir, and A. Syahrani, (2012) "Activity Test of Nanogold for Reduction of Free Radicals, a Pre-Assessment Utilization Nanogold in Pharmaceutical as Medicines and Cosmetics," J. Mater. Sci. Eng. B. $\quad$ Retrieved from https://d1wqtxts1xzle7.cloudfront.net/47682493/Journal_of_Materials_Sc ience_and_Enginee20160731-30512-13n6177-with-cover-page-

v2.pdf? Expires $=1637147987 \&$ Signature $=$ LUigmt20oVNu-

fyAK85oznyMGBx44ZsbPNV8jNcvwfev2U4If pLkixS3ccMCfohhqouusFjAt 7Ku0IbVeM07UzgC8UCXRpUs3Pj1Zh9izHZj2sTJqk7uS 5A7XM W0KZW mwjwZEiC3vbxMRyj7aEEjN9g3c2v57pQdC-5XKQQvpMSmrhh8xAizdPCiFL37dUgUsZQgv0fBoP-

GR01ayWJMml5DORT17NtAtwpNXwhM2FGQXk0zL7cW B6JRb61HKViqk tvX8XbKk4yizx2TrNozSFKopNNUuwZF2642Ke2pSAS KASguNimB7rz0jF Foa7BJNPyo0RIaQwqv2fTQ_\&Key-Pair-Id=APKAJLOHF5GGSLRBV4ZA

T. Taufikurohmah, R. Rusmini, and D. Soepardjo, (2021) "Aplication of nanogold and nanosilver to reduce rheumatic arthritis: Case study at leprosy patients," J. Phys. Conf. Ser., vol. 1869, no. 1. Retrieved from https://doi.org/10.1088/1742-6596/1869/1/012018 